\title{
Establishment of persistent infection of measles virus in Vero cells with special reference to the temperature-sensitivity of parent viruses
}

\author{
Eiji Watari, Mikio Adachi, Masanobu Yamanaka, and Yukio Yamazi \\ Department of Microbiology and Immunology, Nippon Medical School
}

Persistent infection of cultured cells by measles virus has been reported by several authors ${ }^{1-13}$, and several mechanisms responsible for the establishment and the maintenance of this state have been proposed. These include the selection of the host cells resistant to the release of infectious units ${ }^{3,7,10)}$, inherent nonpermissiveness to measles virus of nonproliferating cells $^{8}$, host-controlled variation of the carried virus ${ }^{2}$, defective particle inhibition of virus replication ${ }^{1,0)}$.

However, certain data ${ }^{0,8,9,11,10)}$ have suggested that temperature-sensitive (ts) viruses could be responsible for the maintenance and/or the development of the persistence. Although this hypothesis is also applicable to other virus/cell systems, the possibility can not be definitely ruled out that ts virus arises after development of persitence and that the two phenomena reflect independent but co-selected viral mutations.

In the present brief report we provide evidence that persistently infected Vero cell lines were established from Edmonston strain as well as from a ts mutant ${ }^{15}$ ) of measles virus. The procedure included the long incubation of up to 54 to 92 days of infected cultures without cell-passage.

It was observed that less than one per cent of the cells survived, when a Vero cell culture in a $3 \times 5 \mathrm{~cm}$ square bottle was inoculated with less than $8 \times 10^{4}$ plaque forming units (PFU) of Rapp clone ${ }^{16)}$ of Edmonston virus, which had been passaged without dilution, and incubated at $37^{\circ} \mathrm{C}$ as a stationary culture in $4 \mathrm{~m} l$ of Eagle's MEM supplemented with 5 per cent calf serum for 13 days. The surviving cells were trypsinized to make the first passage. In the present experiments cell cultures were incubated at $37^{\circ} \mathrm{C}$. After 19 days of incubation, the passaged culture was substituted with fresh Vero cells and incubated for further 72 days giving rise to a new cell population from those survived from the syncytial cytopathic effect (CPE). The culture was serially trypsinized and replated with intervals of 54,15 , and 47 days to make the 5th passage, which contained up to $2.4 \times 10^{2} \mathrm{PFU}$ of virus in $0.1 \mathrm{ml}$ of the culture fluid, thus a Vero cell line, R 5-PI-Vero was established. Persistent infection in this cell line has been maintained, to date, after 35 subcultures over a period of 4 years.

Another persistently infected cell line was derived from Vero cells infected with the Rapp virus ${ }^{16)}$, incubated at $42^{\circ} \mathrm{C}$ for the first 2 days of infection in order to inhibit ts population of the virus. The culture developed $\mathrm{CPE}$ after 16 days of incubation at $37^{\circ} \mathrm{C}$ and gave rise to a new cell population from survived cells. The culture was serially passaged with intervals

\footnotetext{
Present address : Department of Microbiology and Immunology, Nippon Medical School, 1-1-5, Sendagi, Bunkyo-
} ku, Tokyo, 113 Japan 
$-80-(148)$

of 9 to 91 days until the 6th passage over a period of 200 days. Each of the passaged cultures developed CPE before giving rise to a new cell population from survived cells. The 6th passaged culture of this cell line, R 5-PHI-Vero, contained $1.9 \times 10^{3} \mathrm{PFU}$ of virus in $0.1 \mathrm{~m} l$ of frozen and thawed extract of the culture.

The third persistently infected cell line was obtained from a Vero culture infected with a ts mutant, $\mathrm{p}-448^{15}$ ) of measles virus, at an input multiplicity of approximately $0.01 \mathrm{PFU} /$ cell. At the 25th passage, $0.1 \mathrm{ml}$ of frozen and thawed extract of the culture contained 1.0 $\times 10^{4} \mathrm{PFU}$ of infective virus, and up to date, survived cells have been serially replated 35 times with intervals of 4 to 92 days over a period of 4 years. Thus a persistently infected Vero cell line, 448-PI-Vero has been maintained.

The growth characteristic of these persistently infected Vero lines does not so differ from that of uninfected Vero cells, except that it took rather longer time to make complete monolayers when the replating time coincided with the period of progressive CPE-development of the culture.

Development of CPE and virus yield of the persistently infected cultures is described in Tables 1 and 2. About 50 per cent of the 5th passaged R 5-PI-Vero cells showed CPE after 6 to 10 days of the passage and then a new cell population developed. During this period virus yield roughly paralleled to the degree of syncytial CPE. From the 79th to 90 th days cells progressively degraded and again a new cell population grew out on the 148 th day, but virus yields were low during this period. Hemagglutinin (HA) titers, determined with African green monkey erythrocytes, were $1: 32$ on 55 th and 71 st days after

Table 1 Virus yield from R 5-PI-Vero cultures

\begin{tabular}{cccc}
\hline $\begin{array}{c}\text { Days } \\
\text { after } \\
\text { passage }\end{array}$ & \multicolumn{3}{c}{ Virus yield (PFU/0.1 ml) } \\
\cline { 2 - 4 } & $\mathrm{R} 5$-PI-Vero-5** & R 5-PI-Vero-14 & R 5-PI-Vero-20 \\
\hline 1 & $\mathrm{ND}$ & $\mathrm{ND}$ & $2.7 \times 10^{2}(0)$ \\
2 & $\mathrm{ND}$ & $\mathrm{ND}$ & $1.4 \times 10^{2}(0)$ \\
4 & $4.2 \times 10^{1}(1) 1: 4^{*}$ & $1.0 \times 10^{1}$ & $6.5 \times 10^{2}(1)$ \\
6 & $4.3 \times 10^{1}(2)$ & $\mathrm{ND}$ & $8.3 \times 10^{1}(1)$ \\
7 & $1.7 \times 10^{2}(2)$ & $\mathrm{ND}$ & $1.8 \times 10^{2}(1)$ \\
8 & $2.4 \times 10^{4}(2)$ & $7.8 \times 10^{1}(2)$ & $1.3 \times 10^{2}(1)$ \\
9 & $2.0 \times 10^{2}(2)$ & $\mathrm{ND}$ & $4.1 \times 10^{1}(1)$ \\
10 & $1.1 \times 10^{2}(2)$ & $\mathrm{ND}$ & $1.9 \times 10^{1}(2)$ \\
12 & $2.7 \times 10^{1}(1)$ & $3.5 \times 10^{1}(\mathrm{R})$ & $3.4 \times 10^{1}(2)$ \\
16 & $8.9 \times 10^{\circ}(1)$ & $2.6 \times 10^{2}(\mathrm{R})$ & $3.0 \times 10^{1}(2)$ \\
19 & $<1(1)$ & $5.0 \times 10^{2}(\mathrm{R})$ & $2.4 \times 10^{1}(2)$ \\
22 & $\mathrm{ND}$ & $8.8 \times 10^{2}(\mathrm{R})$ & $1.6 \times 10^{2}(1)$ \\
34 & $\mathrm{ND}$ & $5.4 \times 10^{2}(\mathrm{R})$ & $2.0 \times 10^{1}(1)$ \\
53 & $5.1 \times 10^{1}(1)$ & $4.9 \times 10^{2}(\mathrm{R})$ & \\
55 & $1.5 \times 10^{1}(1) 1: 32^{*}$ & $1.5 \times 10^{2}(\mathrm{R})$ & \\
67 & $<1(1)$ & $7.1 \times 10^{2}(\mathrm{R})$ & \\
71 & $<1(1) 1: 32^{*}$ & & \\
75 & $3.0 \times 10^{1}(1)$ & & \\
79 & $5.5 \times 10^{\circ}(2)$ & & \\
90 & $2.8 \times 10^{\circ}(3) 1: 8^{*}$ & & \\
99 & $<1(3)$ & & \\
148 & $1.9 \times 10^{1}(1)$ & & \\
\hline
\end{tabular}

Grade of CPE is shown in parenthesis: (1) less than $25 \%$, (2) 25 to $50 \%$, (3) 50 to $75 \%$. (4) more than $75 \%$ of cells show CPE. *HA titer. ${ }^{* *}$ The last figures are passaged numbers. 
Table 2 Virus yield from 448-PI-Vero and from R 5-PHI-Vero cultures

\begin{tabular}{|c|c|c|c|}
\hline \multirow{2}{*}{$\begin{array}{l}\text { Days } \\
\text { after } \\
\text { passage }\end{array}$} & \multicolumn{3}{|c|}{ Virus yield $(\mathrm{PFU} / 0.1 \mathrm{~m} l)$} \\
\hline & 448-PI-Vero-8** & 448-PI-Vero-19 & 448-PI-Vero-25 \\
\hline 1 & ND & ND & $4.7 \times 10^{\prime}(1)$ \\
\hline 2 & ND & ND & $2.2 \times 10^{8}(1)$ \\
\hline 3 & $1.2 \times 10^{8}$ (1) $1: 16^{*}$ & ND & $1.0 \times 10^{4}(1)$ \\
\hline 6 & ND & ND & $2.9 \times 10^{4}(2)$ \\
\hline 7 & ND & ND & $3.6 \times 10^{8}(2)$ \\
\hline 8 & ND & $1.0 \times 10^{\circ}$ & $2.2 \times 10^{8}(2)$ \\
\hline 9 & ND & ND & $5.8 \times 10^{2}(2)$ \\
\hline 11 & $6.6 \times 10^{1}(1)$ & $1.8 \times 10^{2}(2)$ & $8.0 \times 10^{1}(2)$ \\
\hline 13 & ND & ND & $1.4 \times 10^{\circ}(2)$ \\
\hline 17 & $1(1)$ & ND & $5.0 \times 10^{1}(1)$ \\
\hline 20 & ND & ND & $1.1 \times 10^{\circ}(1)$ \\
\hline 23 & $3.4 \times 10^{\circ}$ (2) $1: 32^{*}$ & $2.7 \times 10^{2}(1)$ & $8.0 \times 10^{1}(1)$ \\
\hline 30 & $6.7 \times 10^{1}$ (1) $1: 4^{*}$ & $2.1 \times 10^{2}(0)$ & $1.3 \times 10^{2}(1)$ \\
\hline 36 & $3.3 \times 10^{\circ}(1)$ & $1.1 \times 10^{2}(0)$ & \\
\hline 47 & $3.6 \times 10^{1}$ (2) $1: 4^{*}$ & $1.7 \times 10^{2}(\mathrm{R})$ & \\
\hline 60 & $1(2)$ & $6.3 \times 10^{4}(\mathrm{R})$ & \\
\hline 67 & $1.7 \times 10^{1}(2)$ & $8.8 \times 10^{2}(\mathrm{R})$ & \\
\hline Days after passage & R 5-PHI-Vero-4** & R 5-PH & \\
\hline 3 & $1.3 \times 10^{1}(1)$ & ND & \\
\hline 4 & $6.8 \times 10^{1}(1)$ & $2.6 \times 10$ & \\
\hline 6 & $1.3 \times 10^{2}(3)$ & ND & \\
\hline 43 & $3.1 \times 10^{1}$ (2) $1: 64^{*}$ & $1.9 \times 10$ & \\
\hline 61 & $9.3 \times 10^{1}(1)$ & $4.5 \times 10$ & \\
\hline 67 & $1(1)$ & ND & \\
\hline 76 & $8.8 \times 10^{\circ}$ (3) $1: 64^{*}$ & ND & \\
\hline 87 & $1.3 \times 10^{\circ}(2) 1: 32^{*}$ & ND & \\
\hline 122 & $3.4 \times 10^{\circ}(2)$ & $1.9 \times 10$ & \\
\hline
\end{tabular}

Grade of CPE is shown in parenthesis : (1) less than $25 \%$, (2) 25 to $50 \%$, (3) 50 to $75 \%$. (4) more than $75 \%$ of cells show CPE. *HA titer. **The last figures are passaged numbers.

passage, which is rather high in contrast to those formed in the lytically infected Vero cells with Edmonston virus. These figures might reflect defective, incomplete particles in the culture. In the 14th passage, rounded cells were observed from the 12th day, which were of relatively large size arising from the monolayer with swollen nuclei containing tubular structure under the electron microscopy ${ }^{11}$ ) and these cells gave rather high virus yields. In the 20th passage, about 50 per cent of the cells showed the syncytial CPE after 10 to 19 days after cell passage, then a new cell population grew out and virus yields were $1.9 \times 10$ PFU or more per $0.1 \mathrm{~m} l$ of frozen and thawed extracts of cultures throughout for 34 days after passage.

The 4th passaged R 5-PHI-Vero culture showed syncytial CPE in about 75 per cent of cells with relatively high virus yield on the 6 th day, before a new cell population grew out on around the 61st to 67th days. A progressive cell degradation was observed after the 76 th day with low virus yield. HA titer on the 43rd, 76th, and 87th days would reflect incomplete particles. At the 6th passage, rounded cells appeared with rather high virus yields.

The 8th and 19th passaged 448-PI-Vero cultures could be maintained for more than 67 days. On the 3rd day of the 8th passage, virus yield was high, but it gradually decreased 
$-82-(150)$

and 1:32 of HA titer was observed with very low virus yield. The 19th passage gave relatively high virus yields from 11 to 67 days without any correlation to CPE. In the 25th passage, about 50 per cent of the cells showed syncytial CPE from the 6th to 13 the day, and more than $8.0 \times 10 \mathrm{PFU}$ of virus was determined throughout for 30 days after passage.

From these data, it is concluded that temperature-sensitivity is not indispensable prerequisite for the persistency of the measles virus in Vero cells, because persistently infected cell lines were established from a ts mutant ${ }^{15)}$ as well as the original wild Rapp clone ${ }^{16)}$ of Edmonston virus, and R 5-PHI-Vero was exposed to a high temperature in the beginning of the infection. Relatively high HA titers accompanied with low infective virus titers, found in the 4 th and 8th passage of these persistently infected cultures, may suggest that defective incomplete particles are involved in developing the persistency.

However, 448-PI-Vero is more stable as a carrier culture than R 5-PI-Vero, i. e. the latter sometimes underwent the transition to the lytical infection with unknown reasons. This suggests a mutation of $\mathrm{P}-448$ virus $^{15}$ ) should contribute to the development and maintenance of the persistency.

Presice characteristics of these persistently infected Vero cell lines are now under investigation.

\section{REFERENCES}

1) Rustigian, R. : Virology, 16, 101, 1962

2) Minagawa, T. : Japan, J. Microbiol., 15, 325, 1971

3) Rustigian, R. : J. Bact., 92, 1792, 1966.

4) Restigian, R. : J. Bact., 92, 1805, 1966; Winston, S.H., Rustigian, R., and Bratt, M.A. : J. Virol., 11, 926 , 1973.

5) Minagawa, T. : Japan J. Microbiol., 15, 333, 1971.

6) Norrby, E. : Arch. ges. Virusforsch., 20, 215, 1967.

7) Knight, P., Duff, R., and Rapp, F. : J. Virol., 10, 995, 1972

8) Haspel, M.V., Knight, P.R., Duff, R.G., and Rapp, F. : J. Virol., 12, 690, 1973.

9) Gould, E.A., and Linton, P.E. : J. gen Virol., 28, 21, 1975.

10) Menna, J.H., Collins, A.R., and Flanagan, T.D. : Infect. and Immun., 11, 152, 1975.

11) Chiarini, A., Sinatra, A., Ammatuna, P., and Distefano, R. : Arch. Virol., 52, 47, 1976; Chiarini, A., Ammatuna, P., Distefano, R., and Sinatra, A. : Arch. Virol., 56, 263, 1978.

12) Armen, R.C., Evermann, J.F., Truant, A.L. : Arch. Virol., 53, 121, 1977.

13) Wild, T.F., and Dugre, R. : J. gen. Virol., 39, 113, 1978.

14) Preble, O.T., and Youngner, J.S. : J. Inf. Dis., 131, 467, 1975

15) Yamazi, Y., and Black, F.L. : Medicine and Biology (Tokyo), 84, 47, 1972; Yamazi, Y. : J. Nippon Med. Sch., 39, 8, 1972; Yamazi, Y., Black, F.L., Honda, H., Todome, Y., Suganuma, M., Watari, E., Iwaguchi, H., and Nagashima, M. : Japan J. Med. Sc. Biol., 28, 223, 1975; Yamazi, Y., Black, F.L., and Watari, E. : J. Nippon Med. Sch., 44, 292, 1977.

16) Seligman, S.J., and Rapp, F. : Virology, 9, 143, 1959.

17) Yamazi, Y., Watari, E., Yamanaka, M., Adachi, M., and Kyono, S. : The 25th General Meeting of Soc. for Japan. Virol., 1977. 